\title{
Forced Emergence of Title to Land Lots as a Phenomenon of Russian
}

\section{Law}

\author{
Aleksey Anisimov ${ }^{1} \&$ Galina Zemlyakova ${ }^{2}$ \\ ${ }^{1}$ Volgograd Institute of Management, Branch of the Russian Academy of National Economy and Public \\ Administration under the President of the Russian Federation, Russia \\ ${ }^{2}$ Institute of State and Law of the Russian Academy of Sciences, Russia \\ Correspondence: Aleksey Anisimov, Volgograd Institute of Management, Branch of the Russian Academy of \\ National Economy and Public Administration under the President of the Russian Federation, Russia. E-mail: \\ anisimovap@mail.ru
}

Received: April 28, 2019

doi:10.5539/jpl.v12n2p53
Accepted: May 14, $2019 \quad$ Online Published: May 30, 2019

URL: https://doi.org/10.5539/jpl.v12n2p53

\begin{abstract}
The paper studies the legal enforced emergence of private and public title of compulsory origin to land plots in the Russian Federation which is not typical for the European legal practice. The authors examine the causes and consequences of its appearance and note that this is due to the national specifics of Russia's transition to a market economy and a rule-of-law state. The article analyzes legal procedures for the forced reissuance of the right of permanent (unlimited) property use, the emergence of the right of common share ownership of citizens who are the owners of a premises (apartments) in multi-family residential house, the forced transfer to public property of heirless estate, redistribution of landed property among different levels of public authority, transfer of a land lot which cannot by law belong to a citizen or a legal entity to public property, as well as a number of others issues.

The authors believe that the legal practice of the compulsory emergency of the right to own land plots is in many respects a necessary condi-tion for securing important public interests which is inadmissibility of the existence of an ownerless estate where condition may threaten life, health and other legally protected goods, the invasion of land in civil circulation, attraction of additional financial resources to the Federal, regional and municipal budgets through the collection of land tax (or rent payment in the case of forcing the owner of the property to include a joint leasehold agreement).
\end{abstract}

Keywords: right of permanent (perpetual) use, land lot, multi-family residential house, heirless estate, unauthorized construction

\section{Introduction}

Basic land property legal procedures and regulatory definition have arguably been settled in Russian legal science and legislation for many years. So, for example, the grounds for terminating the title to land lots are often divided into voluntary and compulsory in the scientific and educational literature (Ulyukaev, Churkin and others, 2010). Thus, the phrase "compulsory cessation of ownership" has become quite familiar. More than that, since the law establishes the presumption of voluntary acceptance of the relevant decision by the owner the grounds for the termination of the right to property in compulsory order constitute an exclusive legal regime (Ivanchak, 2014). In this respect, the very idea that property rights in the Russian Federation can be forced to emerge seems unrealistic and is completely unconventional.

Despite this fact, further in our paper we will try to justify the existence of forced emergence of title to land lots in Russian land and civil legislation of recent years. That is why the purpose of this paper is to study the norms of Russian land and civil law which regulate the forced emergence of ownership of land lots.

It should be specified that in compliance with Russian law, independent real estate objects include land lots and everything that is firmly connected with the land, that is, the things which movement without disproportionate damage to other location is impossible, including buildings, structures, objects of unfinished construction (Article 130 of the Civil Code of the Russian Federation (hereinafter referred to as the Civil Code of the Russian Federation). At the same time, unity principle of land plots and the constructions which are firmly connected with them is presumed both in civil (Article 552 of the Civil Code of the Russian Federation) and in land 
legislation (Article 1 of the Land Code of the RF (hereinafter referred to as the Land Code of the Russian Federation). Due to the fact that the title to land in Russia emerged only in the 1990s, in many cases the owner of the building is not the owner of the land on which it is located.

That is why, the application of legal regulations for the compulsory emergence of title of citizens and legal entities to land plots is mostly aimed making the owner of the building (or the premises therein) and the owner of the land on which it is located, to be the same person. This is done by the legislators to ensure that land and building on it are recognized as a single object and participate in civil turnover as one immovable thing in future. This measure is also aimed at changing norms of legislation regulating the privatization of buildings and stipulating that such privatization as a general rule is possible only with simultaneous privatization by an individual of both land plots and buildings on them (Paragraph 7, Article 3 of Federal Law No. 137-FZ of October 25, 2001, FZ "On the implementation of the Land Code of the Russian Federation", paragraph 1 of Article 28 of the Federal Law of December 21, 2001 No. 178-FZ "On the Privatization of State and Municipal Property"). Further on we will propose to classify the cases of compulsory emergence of title to land plots and will make a number of constructive proposals on this topic.

\section{Methods}

In the article the author applies the system analysis method, comparative-legal method, historical analysis method,

and statistical method.

\section{Results and Discussion}

\subsection{Re-registration of Permanent (Perpetual) Use Right of Land Plots by Legal Entities}

Incoherence in legal regimes of land plots as objects of civil rights predetermine the legislative peculiarities of title emergence to them (Gryada, 2012). To begin with, it should be stipulated that the legal procedure of enforced emergence of property rights extends not only (and even not so much) to citizens and legal entities, but to public legal entities. In addition, there are specific features applied to legal entities which have been given responsibility to re-register the right of permanent (unlimited) use of land (kind of limited property rights of citizens and legal entities that arose in the 1920s in the USSR after the abolition of private property there (and is still preserved in Russia). It does not have analogies with European legislation; it is partly similar to emphyteusis) for the right to lease or purchase land plots in ownership (at a reduced price) before July 1, 2012 in accordance with the rules established by chapter V.1 of the Land Code of the Russian Federation. In the above described case, legal entities had the opportunity to choose (between ownership and lease) in forcibly imposed title of land rights.

The use of the land plot on permanent (unlimited) basis by a legal entity which has not fulfilled the obligation of re-registration of such right in a prescribed time is punishable according to Article 7.34 of the Code of Administrative Offenses of the Russian Federation. This is considered to be a continuing offense that is why the period of limitation for the institution of administrative proceedings starts from the detection date of the administrative offense (Paragraph 37 of the Review of the Judicial Practice of the Supreme Court of the Russian Federation No. 5 (2017) approved by Presidium of the Supreme Court of the Russian Federation on December 27, 2017).

Besides, according to the Supreme Court of the Russian Federation, an individual or a legal entity which has not re-registered the right of permanent (unlimited) use is obliged to pay for the actual use of the land plot in the amount of rent on the basis of regulatory legal acts of the subject of the Russian Federation (Paragraph 17 of the Review of the Judicial Practice of the Supreme Court of the Russian Federation No. 1 (2018) was approved by the Presidium of the Supreme Court of the Russian Federation on March 28, 2018).

This means that the preferential rental rate is not applied for such persons.

Thus, on the one hand, the compulsory procedure of re-registration of the title to the land plot is not absolute. Individuals and legal entities have a right to choose between types to right acquisition which implies certain voluntary expression of will. On the other hand, negative consequences in the form of both rental payments (in the standard amount without benefits) and administrative responsibility for failure to fulfill the obligation to re-issue such a right make legal entities re-register the right of permanent (perpetual) use of the land plot.

\subsection{Emergence of Title of Individuals and Legal Entities to the Land Plots on Which the Building Is Located}

Further on we will consider several legal constructions when free will of the legal entities for the title emergence to the land plot is not presumed at all by the legislators. The adoption of such rules was due to the fact that 
"relevant land lots are actually occupied by the owners of buildings, constructions, premises in these buildings. Some (but not all) of these owners have some rights to the land; most of them do not have any title to. Therefore, there is a situation of actual possession without any rights which is abnormal and required elimination and transition to a regime where the owners of buildings (constructions, structures, premises) have certain right to the land." (Sklovsky, 2010).

The first case describes the emergence of common share ownership of individuals, owners of residential premises of a land plot occupied by a multi-family residential house. Originally, part 3 of Article 16 of Federal Law No. 189-FZ of December 29, 2004 "On the Enactment of the Housing Code of the Russian Federation" established that if a land plot on which an apartment building and other premises of immovable property belonging to such house are located was not formed prior to the introduction of the Housing Code of the Russian Federation, on the basis of a decision of the general meeting of premises owners in an apartment building, any person authorized by the said meeting was entitled to apply to state authorities or local self-government authorities with a demand on the formation of the land plot on which such multi-family residential building is located. The constitutional justification of such norms was doubtful, the interested persons appealed to the Constitutional Court of the Russian Federation. The latter indicated that Part 3 of Art. 16 of the Federal Law "On the Enactment of the Housing Code of the Russian Federation" to the extent that it interferes with the premise owner in an multi-family apartment building who is not authorized by the general meeting of the owners of premises of this house to apply to state authorities or local self-government bodies on the topic of formation of a land plot on which an apartment building is located does not comply with the Constitution of the Russian Federation. Before introduction of necessary changes to the federal legislation, owners of premises in apartment buildings whose land plots are not formed, have the right to individually apply to authorized state bodies or local self-government bodies with a demand for the formation of these plots of land. These statements are grounds for the formation of a land plot and its cadastral registration (Decision of the Constitutional Court of the Russian Federation of May 28, 2010 No. 12-П "On the case of the constitutionality verification of Parts 2, 3 and 5 of Article 16 of the Federal Law" On the Enactment of the Housing Code of the Russian Federation ", Parts 1 and 2 of Article 36 of the Housing Code of the Russian Federation, paragraph 3 of Article 3 and paragraph 5 of Article 36 of the Land Code of the Russian Federation in connection with complaints of citizens E.Yu. Dugenets, V.P. Minina and E.A. Plekhanov»).

The specified norm of the federal law has operated in a new version since July 14, 2018. According to new version, any owner of a premise in an apartment building has the right to apply to state authorities or local self-government bodies with a demand to form a land plot on which a multi-family apartment building is located.

Since the date of state cadastral registration of the land plot on which the apartment building is located such a land plot passes free of charge to the common share ownership of the owners of premises in the apartment building (part 3 of Article 16 of the Federal Law "On the Enactment of the Housing Code of the Russian Federation").

Therefore, in the case of sending applications to the authorized public authority by one owner of a residential or non-residential premise in an apartment building, the right of common share ownership of the land plot arises immediately from all rights holders of apartments and other premises, without their consent and even notification. We can assume that individuals are unlikely to be delighted with such innovation, since the emergence of title of common shared ownership in reality will mainly entail a duty to pay land tax.

According to the Tax Code of the Russian Federation, at the moment, land plots which are part of the common property of a multi-apartment building are not subject to taxation. This is due to the fact that land plots under apartment buildings in most cases are not yet formed, and are not transferred to the common equity ownership of the right holders of apartments and other premises. Neverthless, such work is under way, and with the passage of time when a significant number of land plots under multi-apartment buildings will be formed, the necessary adjustments will inevitably be made to the legislation, and the land tax will be collected in full.

It should also be stressed that unlike legal entities that have the choice of compulsory title to the land (property or lease) for individuals who own premises in an apartment building there is no such possibility.

At the same time, the legislation does not presume any refusal of the title of common ownership to a land plot under the apartment building, either individually by the owner of the premise in an apartment building, or collectively on the basis of a general meeting of owners ' decision, From paragraph 1 of Art. 16 of the Federal Law "On the Enactment of the Housing Code of the Russian Federation" and Part 1c. 42 of the Federal Law of July 13,2015 No. 218-FZ "On State Registration of Real Estate" we can conclude that the title to common share of the land plot on which the apartment building is located is inextricably linked and follows the title of the 
individual to the premises in the apartment building.

Therefore, it is impossible to terminate the right to share a common ownership of the land plot on which the apartment house is located without terminating the ownership of the premises in this house. In the legal literature, classification of methods for legal private ownership of land plots acquisition includes administrative and legal as well as civil law aspects (Lisina, 2014).

According to O.I. Krassova, such subdivision of methods is not made on the basis of the title emergence, but with respect to the document on the basis of which the transfer of ownership of land is conducted: a contract of sale or an administrative act on the provision of land (Krassov, 2000).

However, in the case under consideration there is neither a contract nor an administrative act on the provision of a land plot. The compulsory enforcement of right holders of the buildings to acquire land plots on which their buildings are located can also be found in other legislative acts. So, in accordance with paragraph 2 of Art. 39.20 of the Land Code of the Russian Federation, in the event that a building or a construction is located on an indivisible land plot or premises in the said building, the premises belong to several persons on the right of private ownership or on such a plot of land are several buildings and structures belonging to several ondividuals on the right of private property, these persons have the right to purchase the land plot in the common share ownership or to rent it as a joint leasehold.

At the same time, Paragraph 6 of article 39.20 of the Land Code of the Russian Federation provides for the possibility of one of the owners of the building to apply to the authorized body independently with a demand for the provision of a land plot for lease. In this case, the authorized body invites the other potential tenants to enter into a contract, and in case of their refusal, they can apply to the court with a demand to compel the lease contract of joint leasehold on the tenant's side (Paragraphs 6-8 of Article 39.20 of the Land Code of the RF) (Shtukaturova 2018). In addition, even if none of the indicated rightholders has applied for title acquisition to the land plot, the authorized body has the right to apply to the court with a claim to compel the owners of the building to conclude a lease contract for the land plot on which the building is located.

Consequently, these procedures for the compulsory acquisition of ownership of land are primarily aimed at eliminating legal uncertainty in matters of taxation and the legal validity of land plots use on which buildings belonging to private individuals are located. In addition, they contribute to the implementation of one of the basic principles of land legislation that is unity principle of land plots and the constructions which are firmly connected with them. However, all of them are not voluntary.

\subsection{Enforced Emergence of Title to Land Plots of Public Entities}

The next case of compulsory emergence of the right of ownership does not concern citizens but the states. According to the article 1511 of the Civil Code (hereinafter referred to as the Civil Code of the Russian Federation), if there are no heirs, either by law or by will, or none of the heirs has the right to inherit or all heirs are suspended from inheritance, or none of the heirs accepted inheritance, or all the heirs refused the inheritance, and none of them indicated that they refused to benefit another heir, the property of the deceased is considered to be heirless estate.

Heirless estate property in the form of a residential premises, a land plot located on the territory of the Russian Federation, as well as a building, construction or other immovable property located thereon shall be transferred by inheritance by law into the ownership of the municipal entity in which the property is located, and if it is situated in the subject of the Russian Federation, a city of federal significance in Moscow, St. Petersburg or Sevastopol, into ownership of the subject of the Russian Federation. Residential premises are included in the social housing stock. Other heirless estate property passes in the order of inheritance by law into the ownership of the Russian Federation. Heirless estate property passes into the ownership of the relevant public legal institution without an act of acceptance of the inheritance, and also regardless of the registration of hereditary rights and their state registration (Gusakov 2017). It should be noted that, according to some researchers, the inheritance of heirless estate property, as well as everything else, is a right, and not an obligation, which creates very favorable opportunities for corruption and arbitrariness (Rudov, 2017). However, it is difficult to agree with this because, unlike ordinary heirs, who can accept or not to accept the inheritance, the act of accepting the inheritance is not required for the acquisition of heirless estate property by public institution.

According to Art. 1112 of the Civil Code of the Russian Federation, the inheritance includes things that belonged to the testator on the date of opening the inheritance, other property, including property rights and obligations. Thus, the heir cannot get the property if he or she refuses the testator's obligations associated with it, for example, regarding paying off the testator's loans. At the same time, if an individual, an heir can refuse an unprofitable 
inheritance, when the amount of his duties exceeds the volume of benefits received, then public institution cannot refuse to accept escheat property, even if it is not profitable for it. Consequently, regardless of the will of the state or municipal owner, it receives unnecessary or excessively burdened property.

Another similar case is presumed by Art. 54.1 of the Land Code of the Russian Federation. It regulates the order of alienation of privately owned land plots when it is seized in connection with the use of such a land plot in violation of the legislation of the Russian Federation, including the procedure for withdrawal of a land plot on which an unauthorized construction has been built or erected. According to paragraph 5, 10 of the above mentioned article of the Land Code of the Russian Federation, if the land plot on which the unauthorized construction is located and in relation to which there is a legally binding decision of the court to seize it, and the costs of demolishing unauthorized construction or bringing it into compliance with established requirements, as well as the costs of preparing and conducting public tenders exceeded the initial price of the land plot, then such a plot is subject to transfer to the ownership of the municipality.

There are other examples of this legal construction. So, according to the general rule stipulated by Paragraph 1.1 of Article 19 of the Land Code of the Russian Federation, the land plot refused by the owner from the date of state registration of the termination of the ownership goes to property of the urban district, urban or rural settlement or in the case of the location of such land site in the inter-settlement territory (sparsely populated territory, located outside the boundaries of settlements, managed by municipal authorities) to the property of the municipal district at the location of the land plot, and in cities of federal significance to the property of these cities (if the laws of the subjects do not specify that such a land plot goes to the property of municipal entities located on the territories of the said constituent entities of the Russian Federation) (paragraph 3 of Article 18 of the Land Code of the Russian Federation). As a rule, in cases of a private person's refusal from the right of ownership to a land plot, this plot is economically unattractive. Otherwise, the owner of such a site would be able to find a buyer for such a site even at a minimum cost.

Another similar case is fixed in Art. 54.1 LC RF. It regulates the order of alienation of a privately owned land plot when it is seized in connection with the use of such a land plot in violation of the legislation of the Russian Federation, including the procedure for withdrawal of a land plot on which an unauthorized structure has been built or erected. According to paragraph 5, 10 of this article of the RF LC, if the land plot on which the unauthorized building is located and in relation to which there is a legally binding decision of the court to seize it, and the costs of demolishing the unauthorized structure or its alignment with the established ones requirements, as well as costs for the preparation and conduct of public tenders have exceeded the initial price of the land plot, then such a plot is subject to transfer to the ownership of the municipal formation.

There are other examples of this construction. So, according to the general rule, stipulated by Paragraph 1.1 of Article 19 of the Land Code of the Russian Federation, the land plot refused by the owner, is from the date of state registration of the termination of the ownership of it goes to the property of the urban district, urban or rural settlement or in the case of the location of such land site in the inter-settlement territory to the property of the municipal district at the location of the land plot, and in cities of federal significance to the property of these cities (if the laws specify it is not established that such a land plot is the property of municipal entities located on the territories of the said constituent entities of the Russian Federation) (paragraph 3 of Article 18 of the RF LC). As a rule, in cases individual's refusal from the right of ownership to a land plot, this plot is economically unattractive. Otherwise, the owner of such a site would be able to find a buyer for such a site even for a minimum cost.

Besides Art. 238 of the Civil Code provides for the possibility of compulsory transfer of property which by virtue of law cannot belong to a private person, into state or municipal ownership, with compensation to the former owner of the value of property determined by the court. This issue with regard to land plots in more detail is regulated by Federal Law No. 101-FZ of July 24, 2002 "On the Circulation of Agricultural Land". Article 5 of this law refers to the obligation of a person to alienate a land plot from agricultural land or a share in the right of common ownership of a land plot from agricultural land that cannot belong to it on the basis of ownership (if 1) such a person is a foreign citizen, a foreign legal entity, a stateless person, as well as a legal entity in the authorized (share) capital of which the share of foreign citizens, foreign legal entities, stateless persons reserves of more than 50 percent; 2) in the ownership of a private person were agricultural lands, the size of the total area of which exceeds the maximum size, is established by the law of the subject of the Russian Federation). At the same time, if a land plot from agricultural land is put up for auction because it cannot belong to this person on the basis of ownership, (or land share) and has not been acquired by anyone, then such land should be acquired by a constituent entity of the Russian Federation, or in cases established by the law of a constituent entity of the Russian Federation by a municipal entity at the market value prevailing in a given location. In such a way, public 
legal entities are not simply legally obliged to purchase land plots, but also have to pay market value for them.

The given cases of compulsory emergence of title to land plots in public entities are aimed at involving land plots resulting from heirless property or occupied by unauthorized buildings into civil circulation and protection of public interest in the use of lands that provide economic basis for the sovereignty of the Russian Federation and its food independence. However, all these cases go beyond the scope of civil-law ideas of the voluntary acquisition of ownership of real estate, including land.

\subsection{Transfer of Immovable Property from Federal to Municipal Ownership}

For a long time in Russia, the question of whether it is possible to forcefully transfer movable or immovable property from state to municipal property which the bodies of local self-government categorically refuse to take on their balance, has been relevant in Russia.

The most evident manifestation of this situation happened more than ten years ago, when the prosecutor's office tried to force local governments of a number of constituent entities of the Russian Federation to take ownership of waterless hydraulic structures. Being aware that ownership of such real estate implies only colossal expenses instead of profit, local self-government bodies by all means evaded such "gifts".

So, the Volgograd regional prosecutor's office announced illegal a number of demands for recognizing the actions (inaction) of district administrations to force local self-government bodies to take into ownership municipal facilities of hydrotechnical structures, cattle cemeteries (biothermal pits) in 2006, Prosecutors justified their decision by the fact that such objects when ownerless, create an increased danger for living near people. Therefore, the adoption of such measures is necessary to prevent emergencies and natural disasters. The courts of the Ilovlinsky, Leninsky, Bykovsky, Svetloyarsky, Kamyshinsky and several other administrative areas of the Volgograd region have fully satisfied the applications of the prosecutors. Thus, for example, the court collegium on civil cases of the regional court satisfied 11 submissions of the prosecutor of the Danilovsky arear on applications for inaction by the administrations of the village councils to take ownership of hydrotechnical facilities, 7 petitions of the prosecutor of the Rudnyansky arear to convince the administration to take over the balance of the cattle cemetery. Legal scholars did not stay away from discussing this problem either.

In particular, some authors proposed to consolidate in the federal law "the duty of the executive bodies of the Russian Federation in the field of safety of hydraulic constructions to ensure safety, bear the costs of maintenance, repairing, conservation, liquidation of hydraulic structures installed in accordance with the legislation of the Russian Federation for registration in as ownerless property, due to the absence of the owner of a hydraulic structure or when the owner is not established, as well as to establish the responsibility for failure to comply with regulations in the field of safety of hydraulic structures on public authorities of the Russian Federation" (Panova, 2009).

However, this proposal did not get a response from the legislator. It should be noted that the situation in question was quite typical, was not limited only to hydraulic engineering facilities. As a result, the issue of the possibility of compulsory emergence of title to municipal property was examined by the Constitutional Court of the Russian Federation. The applicants in their appeal believed that the current provisions of federal laws allow the possibility of unilateral transfer of federal property to municipal property without the consent of local governments and without adequate compensation for additional costs associated with the operation of the transferred property.

This violates the property rights of municipalities, limits their independence in resolving issues of local importance, puts them in an unequal position with other property owners and, thus, contradicts Articles 8, 130, 132, 133 of the Constitution of the Russian Federation.

Regarding this petition, the Constitutional Court of the Russian Federation explained that by establishing criteria for the composition of property that may be in federal ownership and property of the constituent entities of the Russian Federation, the federal legislation does not exclude the discretion of the authorized bodies of state power of the Russian Federation and state authorities of the subjects of the Russian Federation in determining specific property objects transferred in the municipal property. The lack of ability of municipalities to formulate and defend their position with respect to the relevant property would produce possibility of transferring to municipal ownership property that is least effective in social and economic terms and which is not objectively necessary for resolving issues of local importance. The unconditional acceptance of such property could entail additional expenses for its maintenance and significantly hamper the implementation of the constitutional functions of local self-government. At the same time, the local communities themselves would have to essentially support an object of federal level and activity, which is inconsistent with their constitutional and legal status of the subject of the 
right to exercise municipal power, guaranteed in particular by the right to judicial protection and a ban on restricting the rights of local self-government (Article 133 The Constitution of the Russian Federation).

On this basis, it was concluded that when transferring any object from federal to municipal property it is necessary to take into account the will of the local government, which requires joint and concerted actions by the local government and public authorities of the Russian Federation. Accordingly, it is inadmissible to take a decision to transfer an object from federal to municipal property unilaterally, ignoring the will of local government bodies and the objective necessity of such transfer for local self-government to exercise its powers (Definition of the Constitutional Court of the Russian Federation of December 4, 2007 No. 828-O-П "On the complaint of the head of the administration of the Chita Municipal District of the Chita Region on the violation of constitutional rights by separate provisions of Part 11 of Article 154 of the Federal Law of 22 August 2004, No. 122-FZ "On Amendments and Additions to the Federal Law" On General Principles of the Organization of Legislative (Representative) and Executive Bodies of State Power of the Subjects of the Russian Federation "and" On General Principles of Organization of Local Self-Government in the Russian Federation").

This position of the Constitutional Court of the Russian Federation left its impact and was accepted by the federal legislator. So, it is possible to single out a number of federal laws that do not allow compulsory transfer of federal property to the ownership of the subjects of the Russian Federation and local authorities.

1) the first federal law of the kind specifies that the federal executive body exercising the powers of the property owner (land plots that are within the boundaries of resorts of federal significance) is required to take a decision to transfer from federal ownership to a subject of the Russian Federation's property or to a municipal ownership of land plots within a two-month period from the date of receipt of the relevant proposal of the state authority of a subject of the Russian Federation or a local selg-government authority (Federal Law No. 244-FZ of December 3, 2008, "On the Transfer of Land Plots in the territory of Resort f Federal level in to the Ownership of Subjects of the Russian Federation or Municipal Property, on the Assignment of the Specified Land Plots to Federal Property, or municipal property and on amending the Federal Law "On Specially Protected Natural Territories".).Thus, enforced transfer of land is prohibited.

2) another Federal Law No. 423-FZ of December 8, 2011, "On the Procedure for the Gratuitous Transfer of Military Real Property to the Ownership of the Subjects of the Russian Federation, Cities of Federal Significance in Moscow and St. Petersburg, Municipal Property and on Amending Certain Legislative Acts of the Russian Federation", contains a provision stating that if a higher official of a constituent entity of the Russian Federation, cities of federal significance of Moscow, St. Petersburg or Sevastopol, or with the head of a settlement or the head of a urban district applied for the free transfer of military real property, there is located a military real property subject to gratuitous transfer, federal authorities are obliged to accept within two months from the date of receipt of this application the decision on the free transfer of a military immovable property from federal to the constituent entity`s ownership of the Russian Federation, a city of federal significance in Moscow or St. Petersburg or Sevastopol or municipal property or to refuse such transfer.

Until recently, the possibility of transferring land from one public owner to another was contained in Art. 18, 19 of the LC RF. And the corresponding practice of transferring land from federal ownership to the ownership of RF subjects or municipal entities existed (Order of the Government of the Russian Federation No. 2377-r of December 26, 2011 "On the unrestricted transfer of land plots in the ownership of the Novousmansky municipal district of the Voronezh region and the Shubersky rural settlement of the Novousmansky municipal district of the Voronezh region"). But since March 1, 2015, the federal law came into effect, which introduced chapter V.5 of the RF LC on the free transfer of land plots in federal ownership to municipal ownership or to the ownership of the constituent entities of the Russian Federation. Now Artice 39.31 of the RF LC stipulates that the transfer of the land plot from federal ownership is carried out upon application for its transfer, sent by the head of the municipal formation, the highest official of the subject of the Russian Federation submitted to the federal executive body exercising the powers of the owner of the property. Thus, the consent of the property recipient and compulsory clear expression of will which was formulated by a number of acts of constitutional justice is replaced by the direct expression of will of the subordinate subject in the level of the public structure (Maiboroda, 2015).

At the same time, analysis of articles 39.30 of the Land Code of the Russian Federation which determine the cases and grounds for the gratuitous transfer of land plots from federal to municipal ownership or to the ownership of the constituent entities of the Russian Federation, reflects the new approach of the legislator to regulating the issues under consideration, which indicates a "massive" nature of such transfers. At the same time, this article uses the "residual" principle which consists in listing land plots in federal ownership that are not 
subject to transfer to municipal or to state ownership of the subjects of the Russian Federation.

\section{Conclusion}

To summarize, it can be noted that practice of enforced emergence of private and public title of compulsory origin to land plots in the Russian legislation as a rule entails emergence of additional costs for persons who get the right. The emergence of right may include federal property from heirless estate, of municipal property to a land plot occupied by unauthorized construction, or ownership from private persons to a land plot on which a multi-family residential house is built.

At the same time, the legal practice of the compulsory emergence of the right to own land plots is in many respects a necessary condition for securing important public interests which is inadmissibility of the existence of an ownerless estate whose condition may threaten life, health and other legally protected goods, the involvement of land in civil circulation, attraction of additional financial resources to the federal, regional and municipal budgets through the collection of land tax (or rent payment in the case of forcing the owner of the property to conclude a joint leasehold agreement).

The appearance in Russia of the legal practice so unusual for the European legal order (going beyond the scope of all representations of civil law on the voluntary nature of the emergence of the right to property) is due to the national specifics of Russia's transition to a market economy and a law-governed state, and is in our view temporary. After the transition period is expired, the studied practice will become invalid.

\section{Acknowledgments}

The paper was written with support of the Volgograd Institute of Management - branch of Russian Academy of National Economy and Public Administration under the President of the Russian Federation in the framework of research project No. 03-2018 VIM.

\section{References}

Ershov, V. A. (2009). Everything About Land Relations: Cadastral Registration, Ownership, Purchase and Sale, Rent, Taxes, Responsibility. Gross-Media, ROSBUH, Moscow.

Gryada, E. A. (2012). Legal Problems of Application of Legislation on the Emergence of Rights to Land Plots. Legal issues of real estate, 1, 10-13.

Gusakov, S. Yu. (2017). Replacement of the Party of Executive Production. Practice of executive production, 4, 19-30.

Ivanchak, A. I. (2014). Civil Law of the Russian Federation: General Part. Statute, Moscow.

Krassov, O. I. (2000). The Title to Land. Yurist, Moscow.

Lisina, N. L. (2004). Legal regime of the lands of settlements: Educational and practical guide. Delo, Moscow.

Maiboroda, V. A. (2015). Institute for the redistribution of lands of public property in land law. Russian Justice, 1, $9-12$.

Panova, E. A. (2009). Legal liability for violations of water legislation in Russia. Candidate's thesis in law, 9-10. Moscow.

Rudov, M. V. (2017). Systemic deficiencies in the legal regulation of the acquisition of ownership rights by usucapion, on ownerless things and escheat property in relation to the emergence of a share in the right of shared ownership. Property relations in the Russian Federation, 1, 85-91.

Shtukaturova, D. I. (2018). Joint Leasehold Agreement. Reference legal system "Consultant Plus", access date May 14, 2019.

Sklovsky, K. I. (2010). Property in civil law. Statute, Moscow.

Ulyukaev, V. H. et al. (2010). Land law: a textbook. Private Law, Moscow.

\section{Copyrights}

Copyright for this article is retained by the author(s), with first publication rights granted to the journal.

This is an open-access article distributed under the terms and conditions of the Creative Commons Attribution license (http://creativecommons.org/licenses/by/4.0/). 